European Journal of

Humour Research 3 (1) 1-21

www.europeanjournalofhumour.org

\title{
Construction of gender identities via satire: The case of Juvenal
}

\author{
Massih Zekavat \\ Ph.D. candidate, Shiraz University \\ massihzekavat@gmail.com \\ Farideh Pourgiv \\ Professor of English Literature, Shiraz University \\ fpourgiv@rose.shirazu.ac.ir
}

\begin{abstract}
Many studies underscore the societal aspects of satire, yet its role in the construction of social subjects' identities has been mostly ignored. Since satire has been ubiquitous in various cultures and epochs, and identity is also among the primary contemporary concerns in our globalised and multicultural world, the study of the role of satire in the construction of social subjects' identities can prove to be significantly rewarding. Accordingly, this article aims to investigate how satire can contribute to the construction of gender identity in social subjects. It is proposed that opposition/otherness/difference is the common denominator between satire and gender identity. First, different theories of humour are surveyed to show that opposition is integral to satire. Then, it is conveyed that otherness and opposition are similarly essential in the construction of gender identity in both men and women. As opposition can be a common denominator on the axis of sex, satire can be among the determinants of gender identity construction. In the end, Juvenal's Satire VI is explicated to further illustrate the theoretical argumentation. It is concluded that the opposition essential to satire can coalesce with the integral otherness in gender identity, hence to contribute to its construction.
\end{abstract}

Keywords: satire, humour, gender identity, critical theory, Juvenal's Satire VI. 


\section{Introduction}

Gender identities have been subject to various speculations, and, as Mills (1997: 15) observes, "[d]iscourses structure both our sense of reality and our notion of our own identity" (see also Schiffrin, 1996: 168; Schrauf, 2000: 128). This is while literature can safely be considered a discourse, and some critics (Simpson 2003; Zekavat 2014) have contended that satire can also be categorised as a discourse. Actually, Satires of Horace, one of Juvenal's predecessors, are entitled Sermones, a Latin word that means "discourse." One might suspect, therefore, that the discourse of satire can also be among the determinants of social subjects' gender identities. Finding a common denominator between them can shed light on how satire can contribute to gender identity formation. We will argue in this article that opposition serves as this common denominator. Various theories that discuss identity posit that opposition - otherness, or difference are among the other terms used - is the ground based on which the identity of social subjects is formed. This is while most theories of humour consider incongruity and opposition to be essential to satire.

Although most studies insist on the societal aspects of humour, its role in the formation of social subject's identities has been mostly neglected. This paper contends that as both satire and gender identities are rooted in opposition, satire can function as a determinant of gender identity construction. Still, despite this common denominator, the role of satire in identity construction is hardly explored in previous studies. There are implicit or explicit suggestions in literature, yet they are not fully developed; some studies suggest the role of humour in the construction of social subjects' identities (Attardo 1994, 2008; Archakis \& Tsakona 2005; Twark 2007; Habib 2008; Wright 2011; Schaefer 2013; for more subtle implications see Basu 1999; Carrell 2008; Göktürk 2008; Ruch 2008; Kuipers 2009; Morreall 2009; Condren 2012; Williams 2012; Wedeen 2013; Devi \& Rahman 2014). Davis (2008), for instance, refers to Meyer's (2000) classification of humour's functions into two major categories of unity and division. Unity helps "bring people together in one group," and division separates "the In-group from the Others" (Davis 2008: 554). Other studies relate the appreciation of certain kinds of satire to one's identification with specific identity groups (e.g. Druker 2014; Kochersberger et al. 2014). But these are, by and large, case studies, and there is no comprehensive investigation that can furnish a theoretical ground for a deep understanding of satire's role in the construction of social subjects' identities.

In this article, after exploring the theoretical grounds of the relationship between satire and identity construction, we will offer a reading of Juvenal's Satire VI as a case to illustrate the theoretical discussion. Therefore, this study fills a theoretical gap in scholarship on the convergence of two significant issues: satire as a prevalent phenomenon that can be found across many cultures, and identity as one of the most significant concerns and issues of contemporary, multi-cultural, and globalised world. In this, we will attempt to respond to many contemporary thinkers including Said (1993), and Appiah (2005) who have called for the investigation of the discursive construction of identities, hence to fulfil "[t]he job facing the cultural intellectual," that is to say, "not to accept the politics of identity as given, but to show how all representations are constructed, for what purpose, by whom, and with what components" (Said 1993: 380).

Accordingly, this article intends to convey how satire can contribute to the construction of gender identity in social subjects. First, different theories of humour will be surveyed to show 


\section{European Journal of Humour Research 3 (1)}

that opposition and incongruity are seminal to humour. Then, it will be explained how otherness and opposition are similarly pivotal in the construction of gender identity. As opposition can be a common denominator on the axis of sex, satire can be instrumental in the construction of gender identities. In the end, the theoretical argumentation is illustrated through analysing Juvenal's Satire VI.

One more point should be mentioned before starting the discussion. As Twark (2007) remarks, since it is not easy to distinguish between satire and humour as two distinct concepts, their relationship remains contentious. On the one hand, satire has been considered to be humour's subcategory; on the other hand, satirists frequently resort to humour as a literary mode. We agree with Test (1991) that humour, in varying degrees, is frequently integral to satire, yet this does not imply that all satire features humorous laughter: one might think of George Orwell's Nineteen Eighty-Four (2013), or Jonathan Swift's “A Modest Proposal” (1729) that, though containing humour, rarely make the audience laugh. In other words, the absence of laughter does not mean the absence of humour in satire (see also Twark, 2007: 13). For us, humour is an element that appears in satire with varying degrees and is understood not necessarily as being related to laughter. As a matter of convenience, accordingly, we will consider humour to be integral to satire and will follow Test (1991) in using satire as an umbrella term in this article.

\section{Opposition in humour and satire}

Theories of humour have been broadly classified into three categories: superiority or social; relief, arousal, or psychological; and incongruity, or cognitive theories, most of which heavily rely on opposition and incongruity. Morreall $(1983,2008,2009,2012)$ traces the followers of incongruity theory of humour back to Aristotle, Cicero, Thomas Hobbes, Immanuel Kant, Arthur Schopenhauer, William Hazlitt, Søren Kierkegaard, James Beattie, and Michael Clarke. Of course, (some of) these thinkers also manifest inclinations toward other theories in their works. Another critic, Ruch (2008: 24-25), goes even further by claiming that "there is a widespread agreement that incongruity is a necessary condition for humour". But, for sure, it can be asserted that today incongruity theories are the most prevalent and influential theories of humour.

The notion of internal contrast is essential to many of the definitions that Freud (1964) reviews in his "Introduction" to his Jokes and Their Relation to the Unconscious. Later, he enumerates some characteristics of jokes among which are "the coupling of dissimilar things, contrasting ideas, 'sense in nonsense', the succession of bewilderment and enlightenment" (Freud, 1964: 14). Furthermore, he maintains that besides the teller of the joke and its butt, the existence of a third party, an other, is also necessary in tendentious jokes (Freud, 1964: 100, 158). Interestingly enough, this other is actually a woman in Freud's own example (Freud, 1964: 100). Elsewhere, he suggests the presence of an opposition between 'us' and 'them' in hostile jokes (Freud, 1964: 103, 105). After discussing comic difference and its sources (Freud, 1964: 226), he finally concludes that it is the economy in the expenditure of feeling that causes humour. "Differences in expenditure of this kind arise," he maintains, "between what is expected and what happens" (Freud, 1964: 234). ${ }^{1}$

Bergson (1917) also underlines that the existence of other is necessary for the appreciation of the comic in saying that, "[y]ou would hardly appreciate the comic if you felt yourself isolated from others" (Bergson, 1917: 5). For Bergson, however, laughter arises out of the disparity 
between what one expects of humans and what one expects of mechanisms, out of a reversal of expectation in actual experience. "The laughable element," Bergson (1917: 10) maintains, "consists of a certain mechanical inelasticity, just where one would expect to find the wide awake adaptability and the living pliableness of a human being" (emphasis in the original). So, if, contrary to our expectations, a human being acts like a mechanism rather than an organism, then laughter would ensue. Elsewhere, he remarks that "[a] comic effect is obtained whenever we pretend to take literally an expression which was used figuratively" (Bergson, 1917: 115). Consequently, Bergson's can be considered an incongruity theory of humour (Attardo, 1994: 58).

Morreall (1983) also suggests that cognitive shifts are essential to humour. He maintains that "for the incongruity theory amusement is an intellectual reaction to something that is unexpected, illogical, or inappropriate in some way" (Morreall, 1983: 15). He also observes that such contradiction is not specific merely to incongruity theories of humour but both superiority and incongruity theories rely on "duality or contrast" (Morreall, 1983: 15). Later on, he quotes Pascal (2001) who avers that, "[n]othing produces laughter more than a surprising disproportion between that which one expects and that which one sees" (quoted in Morreall, 1983: 16). The earlier version of Morreall's (1983: 39) own theory of humour maintains that "laughter results from a pleasant psychological shift", and that the "enjoyment of a conceptual shift is both necessary and sufficient for humour"; "the essence of humour lies in the enjoyment of incongruity" (Morreall, 1983: 47). A more recent version of this theory identifies "the playful enjoyment of a cognitive shift [...] expressed in laughter" as "the basic pattern in humour" (Morreall, 2009: 49). Besides the play mode, enjoyment and laughter, Morreall (2009: 50) insists that "a cognitive shift" by which he means "a rapid change in our perception or thought" is essential to humour. In both versions, then, a shift in our perception from what we expect to what we actually experience is essential to humour according to Morreall.

Different linguistic theories of humour, like the Semantic Script Theory of Humour (SSTH; Raskin 1985), the General Theory of Verbal Humour (GTVH; Attardo 2001), and Simpson's (2003) theory of humour, also underline the seminal role of opposition. According to the SSTH, a text must be compatible with two distinct and opposite scripts to be humorous (Raskin 1985; Attardo, 1994: 197, 220; Attardo, 2008: 107-108; Ruch, 2008: 25). Its successor, the GTVH, presupposes six knowledge resources including script opposition, logical mechanism, situation, target, narrative strategy, and language (Attardo, 1994: 223-226, Attardo, 2008: 108-109). So the GTVH also posits that opposition is essential to humour. Simpson (2003) also believes that humour features two stages: prime and dialectic. Dialectic "is characterised by irony in its oppositional mode [...] [and] encompasses the concept of incongruity in the broad humorological sense, functions as a contra-expectation in discourse and tends more to be accessed by recourse to knowledge about typical text structures" (Simpson, 2003: 96).

Likewise, explicating the isotopy-disjunction model (IDM) associated with Greimas (1966), Attardo (2008) declares that it "conceptualises humour as a disjunction (switch, passage) from one isotopy (sense) to another" (107); thereby, he underlines "opposition" as essential to humour (see also Attardo, 1994: 64, 90-91, 95). Attardo (1994) repeatedly mentions the role of opposition and incongruity in humour in reviewing various theories of humour (Attardo, 1994: $107,169,175-178,183,189,234,245)$. He even goes as far as showing that even alliterative humour contains incongruity (Attardo, 1994: 139). In the end, he concludes, "the three major linguistic/semiotic models of humour (IDM, SSTH/GTVH, and bisociation) are conceptually 
close insofar as they are variants of the broader psychological model of incongruity-resolution, currently the main model in humour research" (Attardo, 1994: 332).

\section{Opposition in construction of gender identity}

Modern discussions concerning the role of opposition in the construction of the social subjects' identities begin with G. W. F. Hegel's (1977) notion of dialectic according to which both master and slave inter-depend on each other in their oppositional relationship for their identities to emerge. The notion of otherness in its later developments diverges into three directions: psychoanalysis, deconstruction, and postcolonialism. As the focus of this article is gender identities, we will briefly review various theories to show how otherness and opposition are pivotal in the construction of gender identities.

Simone de Beauvoir (2011) was one of the first thinkers who elaborated on how women have been posited as the absolute Other of men by employing both existentialist and Hegelian insights. She avers that "No group ever defines itself as One without immediately setting up the Other opposite itself" (n.p.). In her Second Sex, she attempts to show how men have set up women as their others in order to define their own identity. She maintains that woman is defined against man: "Humanity is male, and man defines woman, not in herself, but in relation to himself; she is not considered an autonomous being" (n.p.). Furthermore, she cites many authorities including Hegel, Emmanuel Levinas, and Claud Lévi-Strauss, who underscore otherness in identity construction. After claiming that woman "is determined and differentiated in relation to man, while he is not in relation to her; she is the inessential in front of the essential. He is the Subject; he is the Absolute. She is the Other," (n.p.), she cites Levinas (1987) to provide an evidence that proves woman are defined as the other. Levinas (1987: 85, 88) writes,

I think that the absolutely contrary contrary [le contraire absolutement [sic] contraire], whose contrariety is in no way affected by the relationship that can be established between it and its correlative, the contrariety that permits its terms to remain absolutely other, is the feminine. [...] [A]lterity is accomplished in the feminine. This term is on the same level as, but in meaning opposed to, consciousness (original italics).

This passage underscores the pivotal role of otherness in identity formation and exemplifies women as the absolute other.

De Beauvoir (2011) also notes that, "[t]o posit the Woman is to posit the absolute Other, without reciprocity, refusing, against experience, that she could be a subject, a peer" (n.p.). This is the reason behind her most famous claim that rejects any feminine essence. She asserts, "One is not born, but rather becomes, woman. No biological, psychic, or economic destiny defines the figure that the human female takes on in society; it is civilisation as a whole that elaborates this intermediary product between the male and the eunuch that is called feminine. Only the mediation of another can constitute an individual as an Other" (n.p.; emphasis in the original). But as it is evident from this succinct discussion, she mainly emphasises the construction of the female identity through man/woman bipolarity. In other words, the relationship she posits is not reciprocal. Yet, according to Hegelian dialectic, men's sense of identity must also inevitably depend on the other they create in the figure of women.

Monique Wittig (2007) draws on de Beauvoir and contends that women are made to correspond with the idea of a natural femininity that is created for them by men. She agrees with 


\section{European Journal of Humour Research 3 (1)}

de Beauvoir that "woman [...] is only a myth" and argues that the way to challenge this myth is to adopt a materialist analysis and promote a lesbian society (Wittig, 2007: 1638). As women are appropriated both in their minds and their bodies by men, Wittig (2007: 1640) maintains, "[o]nce the class 'men' disappears, 'women' as a class will disappear as well, for there is no slaves without masters". In this, she is clearly following Hegel's dialectic as the mechanism behind the construction of gender identities. In the end, she concludes, "[f]or what makes a woman is a specific social relation to a man, a relation that we have previously called servitude, a relation which implies personal and physical obligation as well as economic obligation ('forced residence", domestic corvée, conjugal duties, unlimited production of children, etc.), a relation which lesbians escape by refusing to become or to stay heterosexual" (Wittig, 2007: 1642). Therefore, woman is defined in a hierarchical relationship as opposed to men. She believes that a paradigm shift to homonormativity can offer an escape for women to be liberated from the subjugating relationship that defines them.

Luce Irigaray (1985: 23) also writes that "[f]emale sexuality has always been conceptualised on the basis of masculine parameters". She further asserts that "[f]or woman is traditionally a use-value for man, an exchange value among men; in other words, a commodity [...]. Women are marked phallicly by their fathers, husbands, procurers. And this branding determines their value in sexual commerce" (Irigaray, 1985: 31). But she extends this otherness from the social subject's environment to her internal dimensions. "She' [i.e. woman] is definitely other in herself" (Irigaray, 1985: 28). The woman, in other words, is plural, hence she always implies a sense of difference from herself. So, Irigaray does not deny that women are identified by men, but she does not stop there. She continues to add that women can find the difference and otherness that is necessary for the creation of a sense of self within themselves. In this way, they do not need to depend on an external other, namely man, to construct their identities, but can rely on their own plurality and internal difference. She criticises Freud on this very basis, because he subordinates female identity to male identity (Mansfield, 2000: 94).

Spivak (1999) also shows how the Europeans have attempted to consolidate their sense of selfhood by representing/creating, and employing, their "Others." She especially emphasises the situation of the colonial subjects and women as Others (for some of her remarks about the role of otherness in gender identity construction and its intricacies, see Spivak, 1987: 145, 208, 259; 1990: 136; 1999: 113, 199, 345, 416, 424, 425-426; Morton, 2003: 67, 99-100). As Morton (2003: 67) notes, Spivak (1988) suggests that "disempowered women receive their political and discursive identities within historically determinate systems of political and economic representation". "My own definition of a woman," Spivak (1987: 77) writes, "is very simple: it rests upon the word 'man' as used in the texts that provide the foundation for the corner of the literary criticism establishment that I inhibit". She goes on to show, however, that this definition deconstructs itself.

Kristeva (1982) also explores the relationship between the I and the Other as well as the liminal question of abjection. She remarks that the abject is opposed to I (Kristeva, 1982: 1) and, in a similar vein to Irigaray, maintains that $I$ becomes the other at its own cost (Kristeva, 1982: 3). She refers to "I/Other, Inside/Outside" oppositions in the formation of the consciousness of subjects (Kristeva, 1982: 7, 9-10, 12). Interestingly enough, she deems laughter to be a way of (dis)placing abjection:

The one by whom the abject exists is thus a deject who places (himself), separates (himself), situates (himself), and therefore strays instead of getting his bearings, desiring, belonging, or refusing. 
Situationist in a sense, and not without laughter since laughing is a way of placing or displacing abjection. Necessarily dichotomous, somewhat Manichaean, he divides, excludes, and without, properly speaking, wishing to know his abjections is not at all unaware of them. Often, moreover, he includes himself among them, thus casting within himself the scalpel that carries out his separations.

(Kristeva, 1982:

In this passage, Kristeva states that a deject employs laughter as well as Manichean dichotomies, hence she suggests a connection between abjection, laughter and opposition. Anyhow, abjection is the necessary condition of identity (Mansfield, 2000: 89), on the one hand; on the other hand, the deject resorts to laughter to (dis)place abjection. In other words, Kristeva is implying the existence of a relationship between laughter and identity. She also talks about "the desire of the other" (Kristeva, 1982: 2) and this is the common feature of her argument with Butler.

Judith Butler's notion of identity is also informed by that of Hegel, and is based on difference. Yet, besides Otherness, desire is also central to her conception of identity. She believes that "[ $\mathrm{t}] \mathrm{he}$ effort of desire to appropriate an object, and through that appropriation to assert its own identity, reveals self-consciousness as that which must relate itself to another being in order to become itself" (Butler, 1987: 44). She maintains that it is a desire for the other or other as the desire that creates identity (Butler, 1987: 46). Therefore, she reformulates the Hegelian dialectic by adding desire, besides otherness, as a determinant of identity construction. Not only does she insist that otherness for her, like de Beauvoir, is pivotal to political activism (Butler, 2004: 240-241), but she even goes further by denying biological essentialism as well. Butler (2004: 64) first acknowledges that "how anatomy looks, how it appears to others, and to myself, as I see others looking at me - this is the basis of a social identity as woman or man". But later on, she argues both gender and sex are constructs, and gender identity is performative. Therefore, heterosexism cannot be an essentially natural orientation. Butler (2004: 19) attempts to show the arbitrariness of gender, sex, and heteronormativity as the regulators of human behaviour. For her, gender identity is merely a copy without any original. So, she promotes a relational, as opposed to autonomous, sense of self. In other words, Butler believes that a subject gets a sense of herself only in relation to others, and notes that it is difference that renders unified identity to be impossible (Butler, 2004: 212).

As it was conveyed in this brief critical review, opposition is seminal in the formation of social subjects' gender identities in different trends of thought. This is true not only with regard to feminine identity but also with regard to men's sense of their self (Scott, 1999: 209). In other words, it is not just the identities of women that depend on men for their existence, men also depend on women for their sense of identity.

\section{Construction of gender identities via satire}

Some of the theories reviewed in section 2 of this article concerned humour rather than satire. But as we are following Test (1991) in using satire as the blanket term, it can be concluded that opposition is essential both to the construction of gender identity in social subjects and to satire. Test (1991: $\mathrm{x}$ ) suggests that satire is a "spirit" and decides to restrict his theoretical framework merely to identifying its basic elements. He further declares that "four elements basic to satire" are "attack or aggression, laughter or humour, play, and judgment", on which he goes on to 
elaborate especially in his first chapter. He also subordinates all humour-related forms of expression including humour, farce, invective, fables, apologues, social criticism, parody, travesty, spoof, comedy, and burlesque under satire in the quadripartite scheme he proposes. The absence or presence as well as the varying degrees of any of these four essential elements distinguish these forms of expression from each other. But, even if one does not agree with this terminology, one might agree with the critics who believe that satire integrates a varying degree of humour, and that humour does not inevitably necessitate laughter (see Twark, 2007: 13). And since humour, as an ingredient of satire, necessitates opposition, satire must also include opposition. Other theories directly relate opposition and reversal of expectation to satire (see Zekavat 2014). In any case, the opposition in satire can coalesce with the opposition necessary for the formation of gender identities, hence contribute to the construction of the gender identities of social subjects.

Although the man/woman binary opposition is present in many satires, it is most obviously evident in sexist satires where it is taken as an essential constituent and functions to unjustly discriminate against one gender, frequently women. Censure, mockery, irony and overstatement are among the devices for creating such a discriminatory tone in sexist satires. But this very bipolarity is also a determinant of the construction of the gender identities of both men and women. Accordingly, the dichotomy man/woman in satire can coincide with the otherness that is the prerequisite of social subjects' gender identity construction, hence to contribute to the formation of masculine and feminine identities. To lend proof to the preceding theoretical discussions, Juvenal's Satire VI (ca. 100-130 [2006]) will be examined in this section in order to convey the workings of the man/woman binary opposition in the creation of sexist satire and how this bipolarity can also contribute to the construction of masculine and feminine identities.

Juvenal has been considered as one of the pillars of satire. Highet (1960) goes so far as writing that "[t]he Roman Juvenal was the greatest satiric poet who ever lived" (Highet, 1960: 2). Though this is a very big claim, Juvenal's status as a satirist and his influence on later generations is a good reason to justify the selection of his work for discussion. Moreover, as Satire VI is a prominent instance of sexist satire by a serious moralising satirist, it provides a clear case for the discussion of the man/woman binary in both satire and identity formation. Besides, Satire VI has been reverberating across many literary traditions both through various translations and by means of adaptations and appropriations during several centuries, which has ensured its ongoing relevance and influence (see Highet 1960; Nussbaum 1976, 1984). Nussbaum (1984: 77, 104) actually believes Juvenal's Satire VI to be "the most sweeping of antifeminist classical satires" that "apparently served as an important source for all subsequent dressing-room scenes" (see also Nussbaum, 1984: 105). Alongside with the ongoing scholarly debates, new translations of Satire VI still appeal to the general audience in the twenty-first century. All these will ensure its ongoing influence and relevance in subsequent ages.

The opening lines of the poem attribute chastity to the already bygone golden age when a good wife,

With skins of Beasts and leaves prepared the bed;

And at her prominent, unwieldy Breast,

Of bulk much fitter to be tapp'd, than prest,

With ever-running streams of wholesome food,

Nourish'd with pleasure her Gigantic brood;

Whilst by her side (tho' hideous to the sight) 
Her windy Husband belch'd and snor'd all night.

(Juvenal, 2006: 51)

Both the incongruity of these descriptions and the opposition between domestic roles are the sources of satire in this passage. Maternity and (grotesque) corporeality are ascribed to ideal women as essential traits that ensure the propagation of the species through procreation and caring for the progeny. An opposition is posited between the roles of men/husbands and women/wives. In the golden past, wives were home-makers, identified by the nourishing qualities of their bodies, while husbands, who were identified by their corporeality in a very different way, merely lied irresponsibly at home. Contrary to that of women and mothers, men's bodily functions mentioned in these lines are not associated with any sense of social responsibility. So in an idealised golden society, the domestic environment is defined by female care versus male indifference.

As the world declines from its virginal state, however, chastity is also substituted by adultery. So, "The Silver-Age which follow'd that of Gold, / Saw Cuckoldom in Capitals inscroll'd" (Juvenal, 2006: 52). But this poem is mainly addressed to men by a man as the male interlocutor of this poem, Postumus, also underscores. So, infidelity is considered to be the folly of women through the male perspective, while the poem for the most part remains silent about men's infidelity to their partners. The persona, furthermore, suggests that Postumus must have lost his wits because he has decided to marry. He asks, "Is there no Rope, no Bridge, no Window nigh, / Where thou [i.e. Postumus] mayst hang, or drown, or fairly die?" (Juvenal, 2006: 52). In other words, it is preferred to die ignobly rather than to be entangled into marriage for a man. Of course, if a man prefers to live, then the persona has another option for him:

Or, if thou yet would'st live - No pathic B-

Whom thou mayst freely, as thou lik'st, enjoy?

One who with broils will not disturb thy rest,

Nor plague thee nightly for some fond request;

Who never counts thy sighs, as Women will,

But moves when bid, and when forbid lies still.

(Juvenal, 2006: 52)

It is recommended to choose a boy as a man's bed-fellow rather than marrying a wife. This is despite Juvenal's attacks on homosexuality in his Satire II and not to be interpreted as his promotion of homosexuality, but rather as his disparagement of marriage and condensation of women through commenting on their sexual voracity (see also Highet 1960). The contrast between a boy's and a wife's sexual behaviour creates a satiric situation, while this very opposition defines their personality as sexual partners. In other words, men expect their wives to totally comply with their sexual desires, while their sexual partners should ignore their own longings. But since this is not what men always find in women, the persona recommends compliant boys, rather than inacquiescent wives, to satisfy their sexual desires.

Reprimanding Postumus for his illusion that he might find a worthy wife, the persona reinscribes the folly of women. He insists that the common lot of husbands is inevitably a "whore": 
But Posthumus [sic] would have a virtuous Wife-

Bleed him, ye Doctors, and preserve his Life!

What - in so lewd an age, expect to find

Morals beyond the pitch of Woman-kind!

Bend rather, Posthumus [sic], and Jove adore,

If thou escape, the Husband's Lot, a Whore.

(Juvenal, 2006: 53)

So women's fidelity and sexual restraint as virtues are put against their lewdness and sexual promiscuity in an age bereft of morality. One reason that can explain this is maternity and role of women in propagation. Patrilineal cultures demand the identification of children's fathers with their natural fathers which can be the cause of concern for men to ensure the fidelity of their wives, hence the legitimacy of their descendents. Accordingly, women's immoral disregard of these 'virtues' makes them an object of satire. The persona continues to provide a reason to justify his morbid attitude towards wives only by generalizing these follies to all women:

... search the Sex, and find out one so pure,

Whom Ceres in her Temple can endure;

Find one whose blood is so subdu'd and tame,

Whom ev'n a Father's kiss shall not inflame ...

(Juvenal, 2006: 53)

The main objection here is toward the transgression of women from the roles that male-defined standards have set for them, and their adherence to an alternative identity that deviates from the one that men try to construct for them. Moreover, one can notice that the attack on wives has given way to an attack on women by now. After the persona continues to extend these traits to all women (Juvenal, 2006: 53-54), he concludes that no woman is worth the attention of any man:

Is there one single Woman worth thy care?

One, for a Wife whom thou may'st safely take,

Whom thou wou'd'st cull and chuse for her own sake?

(Juvenal, 2006: 54)

A man might choose to marry a wealthy wife for the promises of a large dowry in a mercenary marriage of convenience, but no woman is worth the attention of men for her own sake.

One reason behind these reproaches is that all women are considered to be lecherous; hence, all husbands are destined to be cuckolds:

Who weds a Wife but weds her, to enjoy

The common Mistress of some singing Boy-

Some Harper's, Wrestler's Trull, to cross his breed,

And be his Children's Father in his stead.

(Juvenal, 2006: 55)

This necessarily nullifies the claim that men can marry to ensure heredity for themselves. It is also implied that the structure of society is patrilineal, and the requirement of its sustenance is women's (but not men's) fidelity and modesty. Women must deny their desire and pleasure, but 
men (like the singing boy, harper and wrestler) can indulgently enjoy themselves. In other words, the identity of women, especially wives, is constructed as men's others. But the malevolent effect of lust is not merely limited to the dubious identification of one's progeny; it teaches female freaks more horrendous behaviour like murder (Juvenal, 2006: 58). ${ }^{2}$ Besides sexual voracity, a thirst for luxury, pride (Juvenal, 2006: 58-59), ${ }^{3}$ and immodesty (Juvenal, 2006: 63) ${ }^{4}$ are also attributed to women. This inevitably leads to the conclusion that all women are repulsive and no woman is sound in principles and morals (Juvenal, 2006: 59). ${ }^{5}$ Although it might strike us as illogically high, the persona expects wives not to have any flaws at all (Juvenal, 2006: 60). ${ }^{6}$ In other words, Satire VI maintains that women are "over-sexed" (Highet, 1960: 59) "[v]icious, extravagant, quarrelsome, sex-crazy, drunken, gossipy, affected, domineering, lying, treacherous, murderous" (Highet, 1960: 92; see also 101).

Hardly can any space be allotted to love, if one conceives of marriage and women as it is suggested in Satire VI, according to which love will inevitably lead men into subservience and bondage. One might expect happiness to be the result of love, but the poem maintains that love drives a man toward being a "bond-slave" (Juvenal, 2006: 61). Consequently, this contradiction between the audience's expectations and what they encounter creates satire. But this very contradiction between male and female attitudes towards love is also determining their identities. While men are generally depicted as honest in their love for women, emotional abuse characterises women who play on their husbands' sentiments only to dominate them in their conjugal relationship:

If, still more void of sense, thou lov'st thy Wife,

Prepare to be a bond-Slave all thy Life;

For 'tis the constant maxim of the Sex,

To trample on the most submissive necks;

No Woman that once found her Husband lov'd,

To any sense of duty yet was mov'd.

Nay, 'tis their joy, tho' doating to excess,

To wring his heart, and make his Fortunes less ...

(Juvenal, 2006: 61)

The conclusion derived from these retrospections is nothing short of a recommendation for total abstention from marriage for men (Juvenal, 2006: 61). But these attacks are not merely limited to wives, they extend to their mothers, as well (Juvenal, 2006: 62-63). The poem actually makes vice a heritage which is passed from mothers to their daughters in women (Juvenal, 2006: 63).

Yet, the opening lines of the poem declare that women were once (fabled to be) chaste in the golden age, and since the decline of the world from that age, chastity has fled from the earth. Midway through the poem, the persona returns back to explore the reason that explains the bygone state of women:

In ancient times, e'er Rome knew what was waste,

Labour and poverty kept women chaste.

No time for Vice - No dainties to excite -

They work'd all day and hardly slept at night;

Their hands were hard, their Bodies coarsely clad,

Whatever Industry could get, they had;

Whilst, hov'ring near their Walls, the Punic Chief 
Call'd ev'ry Husband hourly to Relief.

(Juvenal, 2006: 64-65)

Therefore, what actually has caused this decline is a transgression from preordained gender roles. More accurately, a change in the class status of women has drastically modified their identities, which, in its turn, has affected the institution of marriage. Women once had to try hard for their livelihood which left them no time or energy for 'vice.' However, post-war luxury has changed women's class. The persona maintains that women's inclination toward lavishness is Luxury's revenge on men who have already defeated her: "Her [i.e. Luxury's] various Streams corrupting as they ran, / Reveng'd the World of her proud Victor, Man" (Juvenal, 2006: 65). Luxury's revenge on humanity is due to women's fault; that is to say, men are not responsible for it. Women are prodigal, hence ashamed of their poverty, yet men's standpoint with regard to luxury is very different. It is not luxury that defines their identity because they can wisely adapt to their circumstances by parsimony (Juvenal, 2006: 67-68). Women's morality (particularly chastity) is a correlate of their economic standing. The more luxury they enjoy, the laxer their morals will be. Men are thrifty, while women are extravagant. Therefore, the opposition of men and women over the issue of luxury not only creates a situation for satire but also determines their sense of identity.

Later on, the persona again returns to women's lechery by referring to some women's sexual preference for eunuchs.

There are by whom soft Eunuchs are preferr'd,

Who love that Incapacity of beard -

How sweet the harmless kiss - How sweet indeed!

They hate preventive draughts, and wou'd not breed.

Critics in this, they have their rules for choice,

Nor are their hearts quite sett upon a voice;

Cutting when young may give the Silver tone,

But 'tis not that, which captivates alone;

When the big Nerve to its full growth extends,

And in two well-proportion'd Testes ends,

Then take, learn'd Artist, take the trenchant blade,

The Barber only suffers in his Trade.

(Juvenal, 2006: 68)

This is yet another instance of transgression from their identities as social breeders responsible for upholding the society. As eunuchs are impotent, such a relationship cannot secure social sustenance through propagation. Their preference proves women's lechery by emphasising that they do not bother with their social responsibilities nor do they adhere to the function defined for sexual intercourse, i.e. propagation. They resort to sexual behaviour merely to gratify their own desires. Yet, a eunuch might seem to promise an alternative to the man/woman binary opposition, but the opposition between man and woman is still at work in here. A eunuch is still a man part of whose genital is amputated, but his penetrative function in sexual intercourse is still considered masculine according to presumed gender roles. So, women are frequently depicted as lecherous, but men are rarely characterised by this trait. A good proof for this is that men's sexuality can be neutralised by amputating their genital, while women will still enjoy 
them even as eunuchs. Hence, it is again the lechery of women versus the asexual nature of men that determines masculine and feminine identities while it also creates a situation for satire.

Learning is yet another axis on which masculinity and femininity are opposed. The persona vehemently warns against learned women: "Of all the plagues that wait on human life, / None so tormenting as a learned Wife" (Juvenal, 2006: 72). He continues to forbid husbands to let their wives gain any accomplishments in learning. So, learning is not recommended for women, while there is no objection to it for men. This is probably because learning is a way through which mastery and sovereignty, which should be denied to women, can be gained. Finally, after enumerating other demerits in women, the persona returns to the murder as some deed of no gravity for women who might resort to it to get rid of their step children (Juvenal, 2006: 79). Here, the persona who has already accused women of murdering their husbands adds the idea of a step-mother's cruelty, as well: "Women their Husband's former Children hate - / The crime in killing them is not so great" (Juvenal, 2006: 79). This finally leads to an ironic inversion. Subverting the picture of mothers as paragons of tenderness, altruism, and virtue, the poem depicts them to be fearsome, instead:

\author{
Beware, ye Wards, nor thoughtless trust too much, \\ Be cautious what ye taste, or smell, or touch; \\ Poison oft lurks when Mothers serve the meat; \\ Let others taste the Lard before ye eat; \\ Your Tutors to the Cup their Lips apply, \\ Their fears will see the Drug with half an eye.
}

(Juvenal, 2006: 79)

Again the contradiction of readers' expectations about maternity coincides with certain aspects of female identity.

Besides the points that we have attempted to highlight, the poem offers many more examples to illustrate the characteristics that the persona ascribes to women. Men are depicted as the victims of different female follies, while hardly any shortcoming is attributed to them, except for their stooping before women. Some critics, however, have suggested that women/wives are not the (only) targets of satire in Juvenal's Satire VI. Freudenburg (2004) reads this poem in a similar manner to the way most critics understand Jonathan Swift's "Modest Proposal" (1729) or some parts of his Gulliver's Travels (2005) where it is actually the proposer/narrator who is the object of satire. According to Freudenburg (2004: 254), “[w] hat we are looking at [...] is Juvenal himself, the madman satirist. He is the show [...] he himself becomes the principal spectacle of uncontrolled ira (647) and rabies (648) that he claims to deplore in 'this sex' (hunc sexum, 648). And there, in that complete loss of control, he again becomes his satire's chief target" (original italics). Accordingly, this is not a satire against women, but a satire against the loss of control and plunge into the world of myths.

In a similar vein, Smith (1980) also attempts to partly exonerate women from bearing all faults by blaming their husbands for the degeneration of marriages, too. As he observes, marriage is a means by which women gain dominance and power, while they do not have any respect for love or fidelity (Smith, 1980: 329). He further suggests that the poem leaves us with a sense that "a macabre reversal of sex-roles has taken place" (Smith, 1980: 329). Smith argues that the audience might conclude that such marriages cannot be fairly ascribed to the defects of just one party. "In fact," he writes, "critics sometimes imply that Juvenal's real target in Satire 6 
is the degeneration of marriages into loveless relationships in which husbands and wives are equally at fault, as they manipulate each other with mutual selfishness and cruelty" (Smith, 1980: 329). After demonstrating how the husband contradicts his wife in almost all respects (Smith, 1980: 330), Smith finally concludes by acknowledging that the main aim of Satire VI is to chastise women, but also adds that, "an important secondary purpose is to attack the husbands as well, not for their callousness, as some think, but for their submissiveness" (Smith, 1980: 330). He reiterates his claim in that "[t]he fault of men, according to this poem, is not that they are selfish and cruel, but that they are too unselfish and generous, and thus fail to look out for their own interests" (Smith, 1980: 331). So, even this variant reading blames men not for their callousness but for their extreme kindness and submissiveness toward women.

Other scholars have also attempted to provide variant readings of this poem. Braund (1992: 71), for instance, argues that Satire VI "is shaped by contemporary discourses about marriage, in particular the treatment of marriage in rhetoric," and regards the poem "as a poetic version of a standard rhetorical set-piece on the theme of whether or not a man should marry", but he still agrees that the speaker, who is not to be identified with Juvenal's mouthpiece, is a misogynist (Braund, 1992: 83). In a similar vein to Freudenburg (2004), Braund (1992: 84) further contends that since the persona's reason is overtaken by rage in the end Juvenal actually undermines his attitude. He concludes that

the poem is not a broadside against women in general but a specific argument against marrying. It also indicates the failure of the speaker's rhetoric: instead of persuading Postumus to remain unmarried, he narrates his decline into marriage and his fall because of marriage

(Braund, 1992:

Highet (1960: 12, 91, 100) also maintains that Satire VI is "against marriage". Similarly, Nussbaum (1984: 77) writes, "[t]he end of satire seems to be to persuade men who are stricken by love's darts that they can extricate themselves from the entrapment of marriage if they can only rid themselves of illusions about women". However, she quickly adds that "Juvenal's central theme is woman's tragedy - her loss of the essence of womanhood and the substitution of maliciousness and corruption" (Nussbaum, 1984: 77-78).

Other critics also agree with her. Hooley (2007: 199) calls the poem "a diatribe against women" and "an example of a prevailing and pervasive misogyny in Graeco-Roman societies". Smith (2008: 114) argues that the object of Satire VI is women and sex. He implies that infidelity is mostly attributed to women and further maintains "[t]he wife's respect for her husband was central to the Roman ideal of marriage" (Smith, 2008: 117). Smith (2008: 118) also contends that

[i]t has rightly been observed that the search by women for equality with sexually unrestrained men posed a particular threat in a culture where, with no reliable method of birth control, female pudicitia was the surest guarantee of the legitimacy of the heir. Equally appalling to the upper-class male, and a prominent theme in Juvenal's poem, is the fact that female sexual promiscuity represents an endangerment to the aristocratic bloodline in the production of heirs. (original italics)

Harrington (2009) and Highet (1960: 100) also link the entropic and revolutionised social order with gender issues in Satire VI. Accordingly, Smith (2008: 118) concludes, female liberation could translate into the reversal of social hierarchy and "the degeneration of the nobility". 
Johnson (1996: 173) also suggests that the poem's message is that "women are inferior". He argues that the main reason that explains that persona's attitude in Satire VI is the uncertainties within the patriarchal system. As the persona comes to understand that patriarchy is not a natural phenomenon, and that it has to be reinvented, he is shocked. Accordingly, he projects his fears and flaws to his other, namely women. Johnson (1996: 179) concludes,

He [the persona] may be beginning to intuit a truth which Judith Butler in her Gender Troubles [sic] could point him towards but which he would likely disbelieve: namely that sexual identity, together with the other social identities that sexual identity activates, so far from being innate, so far from "coming to be" from (and exactly replicating) an eternal substance, is rather something contingent and unique, something that is produced by habits of performativity, that is, by the individual's particular and always imperfect attempts to conform to the ideal that he or she understands his or her society requires him or her to resemble or, better, to incarnate (vague resemblance would be and is, has to be, sufficient, but pure incarnation seems, to an existing individual, particularly to an adolescent one, what is being demanded of him or her).

As transgression from these contingent gender identities clarifies their arbitrariness, the persona comes to understand that gender identity is merely an effect, rather than a cause. The collapse of gender roles, Johnson maintains, accounts for the persona's hatred toward women, himself and his male audience. ${ }^{7}$

As these critiques convey, it is the opposition between men and women that furnishes the occasion for blame and satire while this very opposition is among the determinants of their identities, too. As expounded above, the poem demands that women should follow a set of patriarchal values, among which are sexual priggishness, chastity and fidelity, by means of holding them to ridicule and censure when they transgress any of these ideals. Even their looks are evaluated according to the scale of male standards. The male persona is trying to contrast the status of actual women and wives against the ideal of womanhood which he devises. This process might remind one of Said's argument in his Orientalism (1979), where he contends that the west concocts the other for the creation of its own identity through (mis)representing the east. As occidental identity depends on the representation of the orient as west's other according to Said, men also represent women as their others against whom they construct their identities in Satire VI. In a dialectical relationship, of course, this forms the identities of both men and women.

Opposition between what men expect women to be and what women actually are or men claim they are, thus, is the basic opposition in Juvenal's Satire VI. This is mainly achieved through representing women as men's others based on the man/woman binary. This should not imply that women are weak; on the contrary, women are actually depicted to be very strong and able to disrupt many social institutions. The very act of writing this poem and the persona's anxieties and warnings prove that women are influential and powerful socio-political agents. "[I]n the Sixth Satire," as Highet (1960: 102) writes,

there is no weakness. All the women are strong characters, stronger than their husbands, possessed by furies of ambition, wilfulness, and lust, utterly selfish, boldly irresponsible, courageous, ruthless, remorseless. Evidently the profound spiritual maladjustment from which Rome suffered in Juvenal's day had sucked away the strength of her men and intensified the passions of her women. They were no longer partners, or members one of another, but rivals, or deadly enemies. 
Besides, women's characters and role(s) are defined for them in negative terms by men and in satiric situations that oppose them to men. Therefore, the very dichotomy that causes satire in Satire VI also contributes to the construction of feminine identity. But man/woman and husband/wife bipolarities do not merely identify women; they also construct the identity of men around their opposition to women in a dialectical inter-dependence. For instance, women are defined through their primary social function as breeders, while men's sexuality and desire are defined when the persona recommends that they should take male lovers instead of wives. Moreover, the opposition between men and women leads to a rivalry over sovereignty and authority in Satire VI which makes the persona warn that marriage can often reverse the gender hierarchy by making men subservient to women. Therefore, this sexist satire allots social identities to both men and women simultaneously.

\section{Conclusion}

After suggesting that satire can contribute to the construction of identity formation in (post)colonial situations, Connery and Combe (1995) refer to a gap in scholarship concerning the investigations of satire's function in the construction of identity. This paper attempted to partly fill this gap by exploring how satire can contribute to the formation of gender identities. It was proposed that opposition is a common denominator that can link satire and identity construction. As opposition is essential to satire and satire's incongruity can occur on the axis of sexism, the opposition that creates occasion for satire can also contribute to the construction of gender identity which is, in its own turn, based on otherness and difference. The workings of this mechanism were explored in Juvenal's Satire VI as a follower of a long literary tradition that can be traced back to Semonides of Amorgos, Susarion of Megara, Plautus, and Seneca, among others (see Highet, 1960: 92; Smith 2008) and as a precedent of many other satires that attack women in literary history (see Highet 1960; Nussbaum 1976, 1984).

Two last points demand consideration here. The opposition essential to any satire can contribute to the construction of the gender identity of social subjects in its contemporary episteme. But what if the audience does not identify with the object of satire, as in the case of the sexist satire that attacks women and those women who do not identify with its butt? And what about the impact of a specific satire on the later generations of readers? To answer the former question, we should emphasise that the audience does not necessarily need to identify with the butt of satire for the satire to contribute to their identity formation. To put it more accurately, the element in satire that can contribute to gender identity formation is neither the object of satire nor the audience's sympathies with the satirist and/or the satirised but the discursive circulation and internalisation of satire's implied attitudes which are based on the binary logic that others men and women. What is of significance, therefore, is the opposition that is at work both in satire and in identity construction. One might identify with the butt of a sexist satire, say women, or with its satirist, say a man, or with none. The point though is that the opposition in satire establishes a system of binaries on the axis of sex/gender that creates role models for men and women, and can modify their conceptions of their selves through these acts of othering.

The answer to the latter question demands an independent study and is not within the scope of the present article. The cumulative response of various readers in different epochs and cultures can be studied to show how a certain satire, like Juvenal's Satire VI, has been received by various generations of readers that belonged to different backgrounds. This can lead to a deeper 
understanding of the way through which each specific text has actually formed the gender identities of social subjects through history. But, as Ruch (2008) also notes, disparagement/superiority theory has already offered some useful suggestions to answer this question. This theory explains how humour expresses hostile attitudes (Ruch, 2008: 29, 31). As hostile sexist attitudes are not necessarily time-bound, they can be re-circulated and received across various historical periods and still be the cause of satire. But as sexist attitudes, the constituents of many satiric texts, are based on the man/woman binary opposition, and this very dichotomy is the determinant of gender identity, then it can be concluded that satire can define sexes as opposed to each other, and, therefore, contribute to gender identity formation through othering and difference.

\section{Notes}

${ }^{1}$ For more on the defining role of incongruity in psychological theories of humor, see Ruch (2008).

${ }^{2}$ With what deep art the poison'd Cup they fill, An Husband, or a Son in law, to kill!

What Charms, what Incantations they employ, When hate, revenge, or anger, bids destroy!

${ }^{3}$ But other causes may to Love excite, Sertorius lov'd his Bibula at sight.

He did, 'tis true - for Bibula was fair,

The Face did all - The Wife had little share -

For let but three small Wrinkles mark her face,

Or Age the Muscles of her Skin unbrace;

Let some sharp humor her sound Teeth decay,

Or her once sparkling Eyes but dimly play;

"March, march" (the freed-Man cries) "My Lord commands -

"Already you grow stale upon our hands -

"Your Nose is never dry - You make us sick -

"Begone I say - Nay, no resistance - quick -

"We have another younger in our view,

"Whose Nose may yet be dry, a year or two."

While she, unconscious of impairing Years, Affecting Youth, at home still domineers;

Asks Sheep and Cattle to supply her Board,

And Wine, the best Falernian Grapes afford;

How small a Boon is this - a piece of ground, Cost what it will, must for her use be found; A quantity of Slaves must now be brought An Overseer by whom they may be taught Nothing too rare in Silk, Brocade or StuffHer neighbor has them - is not that enough? No peace - if any Bawble strikes her eye; Shall she want anything which Gold can buy? Let other Merchants live at home at ease, 
Nor tempt, while Winter rages, boist'rous Seas;

No Season stops, no arguments avail,

The Ship is fitted, and the fool must sail.

Each distant Region he must tread, to find

Crystal or Porcelaine Vases to her mind;

Cups of all sorts, with costly Gems inlaid,

And Goblets of the Tears of Myrrh-Trees made;

Nay, if she asks for Berenice's ring,

It must be purchas'd from Judcea's King;

Who, Slave to custom (as their Scriptures say),

Bare-footed celebrates their Sabbath Day;

Whilst Hoggs more honor'd than the Sov'reign Prince,

The folly of their holy Rites evince;

For these from daily pastime never cease,

But live each day alike, and die in peace.

${ }^{44}$ What Courts of Justice from their Broils are free?

To day they join, to morrow disagree!

If as Defendants they have no dispute,

They will turn Plaintiffs, and commence a Suit;

Pleas, Libels, Arguments, and Briefs, will draw,

And tell the Judge, and Lawyer, what is Law.

Drest as Gladiators, and bedawb'd with Oil,

How well they bear each rough Athletic toil!

When in the field of Mars their skill they try,

And in their Manly Sports with Men will vie;

When on the Post deep buryed in the ground,

They strike, and drive the fleeting shivers round.

'Tis Courage fires, not Nakedness that shames,

Or they would celebrate the Floral Games;

For whilst in Armor drest their Sex they b<ear,>

What sense of Modesty can Women <share?>

Yet Mannish as they are in outward show,

They would not for the World their Sex forgoe;

What! change the great Prerogative they boast!

Who give, may feel, who give and take, feel most.

5 "What, none, among such numbers to be found!

"What, none, in Principles, and Morals, sound!"

Not one, my Friend - allow her ev'ry grace,

Let her descend from an illustrious race -

Rich - decent - fruitfull - beyond fancy fair -

And chaste as uncomb'd Sabine Matrons were;

(Tho such a Woman seen on Earth wou'd be

A coal-black Swan - a very Prodigy.)

${ }^{6}$ Some faults indeed are small - it may be so -

But faults are faults, and these no Wife shou'd show. 
7 See also Harrington (2009) for discussions of "gender inversions" and "the performance of gender" in Juvenal.

\section{References}

Appiah, K. A. (2005). The Ethics of Identity. Princeton: Princeton University Press.

Archakis, A. \& Tsakona, V. (2005). 'Analyzing conversational data in GTVH terms: A new approach to the issue of identity construction via humour'. Humour 18 (1), pp. 41-68.

Attardo, S. (1994). Linguistic Theories of Humour. Berlin and New York: Mouton de Gruyter.

Attardo, S. (2008). 'A primer for the linguistics of humour', in Raskin, V. (ed.), The Primer of Humour Research, Berlin and New York: Mouton de Gruyter, pp. 101-155.

Basu, S. (1999). 'Dialogic ethics and the virtue of humour'. The Journal of Political Philosophy 7, pp. 378-403.

Bergson, H. (1917). Laughter: An Essay on the Meaning of the Comic. Trans. Cloudesley Brereton and Fred Rothwell. New York: Macmillan.

Braund, S. H. (1992). 'Juvenal-misogynist or misogamist?'. Journal of Roman Studies 82, pp. 71-86.

Butler, J. P. (1987). Subjects of Desire: Hegelian Reflections in Twentieth-Century France. New York: Columbia University Press.

Butler, J. (2004). Undoing Gender. New York and London: Routledge.

Carrell, A. (2008). 'Historical views of humour', in Raskin, V. (ed.), The Primer of Humour Research, Berlin and New York: Mouton de Gruyter, pp. 303-332.

Condren, C. (2012). 'Satire and definition'. Humour 25 (4), pp. 375-399.

Connery, B. A., and Combe, K. (1995). 'Theorizing satire: A retrospective and introduction', in Connery, B. A. and Combe, K. (eds.), Theorizing Satire: Essays in Literary Criticism, New York: St. Martin's Press, pp. 1-15.

Davis, D. (2008). 'Communication and humour', in Raskin, V. (ed.), The Primer of Humour Research, Berlin and New York: Mouton de Gruyter, pp. 543-568.

De Beauvoir, S. (2011). The Second Sex [eBook]. Trans. Constance Borde and Sheila Malovany Chevallier. New York: Vintage Books.

Devi, G. and Rahman, N. (2014). Humour in Middle Eastern Cinema. Detroit: Wayne State University Press.

Freud, S. (1964). Jokes and Their Relation to the Unconscious. Trans. James Strachey. London: Hogarth Press.

Freudenburg, K. (2004). Satires of Rome: Threatening Poses from Lucilius to Juvenal. Cambridge: Cambridge University Press.

Göktürk, D. (2008). 'Jokes and butts: Can we imagine humour in a global public sphere?' PMLA 123 (5), pp. 1707-1711.

Greimas, A. J. (1966). Semantique structurale. Paris: Larousse. Engl. Tr. (1983). Structural Semantics. Lincoln: University of Nebraska Press.

Habib, R. (2008). 'Humour and disagreement: Identity construction and cross-cultural enrichment'. Journal of Pragmatics 40, pp. 1117-1145.

Harrington, J. M. (2009). Mens Sana: Authorized Emotions and the Construction of Identity and Deviance in the Saturae of Juvenal. Ph.D. dissertation, The University of Michigan. 
Hegel, G. W. F. (1977). Phenomenology of the Spirit. Trans. A. V. Miller. New York: Oxford University Press.

Highet, G. (1960). Juvenal the Satirist: A Study. London: Oxford University Press.

Hooley, D. M. (2007). Roman Satire. Malden: Blackwell.

Irigaray, L. (1985). This Sex Which is Not One. Trans. Catherine Porter and Carolyn Burke. Ithaca: Cornell University Press.

Johnson, W. R. (1996). 'Male victimology in Juvenal 6'. Ramus 25, pp. 170-186.

Juvenal. (2006). 'Juvenal Book 2nd: Satire 6th: Englished against Women', Trans. William Popple. Translation and Literature 15, pp. 51-82.

Kairoff, C. T. (2007). 'Gendering satire: Behn to Burney', in Quintero, R. (ed.), A Companion to Satire, Malden: Blackwell, pp. 226-292.

Kochersberger, A. O., Ford, T. E., Woodzicka, J. A., Romero-Sanchez, M., Carretero-Dios, H. (2014). 'The role of identification with women as a determinant of amusement with sexist humour'. Humour 27 (3), pp. 441-460.

Kristeva, J. (1982). Powers of Horror: An Essay on Abjection. Trans. Leon S. Roudiez. New York: Columbia University Press.

Kuipers, G. (2009). 'Humour styles and symbolic boundaries'. Journal of Literary Theory 3 (2), pp. 219-240.

Levinas, E. (1987). Time and the Other. Trans. Richard A. Cohen. Pittsburgh: Duquesne University Press.

Mansfield, N. (2000). Subjectivity: Theories of the Self from Freud to Haraway. St. Leonards: Allen \& Unwin.

Meyer, J. C. (2000). 'Humour as a double-edged sword: Four functions of humour in communication'. Communication Theory 10, pp. 310-331.

Mills, S. (1997). Discourse. London and New York: Routledge.

Morreall, J. (1983). Taking Laughter Seriously. Albany: State University of New York.

Morreall, J. (2008). 'Philosophy and religion', in Raskin, V. (ed.), The Primer of Humour Research, Berlin and New York: Mouton de Gruyter, pp. 211-242.

Morreall, J. (2009). Comic Relief: A Comprehensive Philosophy of Humour. West Sussex: WileyBlackwell.

Morreall, J. (2012). 'Philosophy of humour', in Zalta, E. N. (ed.), The Stanford Encyclopedia of Philosophy, Spring 2013 Edition. URL: http://plato.stanford.edu/archives/spr2013/entries/humor/ [Accessed 24 November 2014].

Morton, S. (2003). Gayatri Chakravorty Spivak. London and New York: Routledge.

Nussbaum, F. (1976). 'Juvenal, Swift, and The Folly of Love". Eighteenth-Century Studies 9 (4), pp. 540-552.

Nussbaum. F. A. (1984). The Brink of All We Hate: English Satire on Women 1660-1750. Kentucky: The University Press of Kentucky.

Orwell, G. (2013). Nineteen Eighty-Four. London and New York: Penguin.

Pascal, B. (2001, reproduced in electronic form). The Provincial Letters. Louisville: Bank of Wisdom.

Raskin, V. (1985). Semantic Mechanisms of Humour. Dordrecht: D. Reidel.

Ruch, W. (2008). 'Psychology of humour', in Raskin, V. (ed.), The Primer of Humour Research, Berlin and New York: Mouton de Gruyter, pp. 17-100.

Said, E. W. (1979). Orientalism. New York: Vintage Books.

Said, E. W. (1993). Culture and Imperialism. London: Chatto \& Windus. 
Schaefer, Z. A. (2013). 'Getting dirty with humour: Co-constructing workplace identities through performative scripts'. Humour 26 (4), pp. 511-530.

Schiffrin, D. (1996). 'Narrative as self-portrait: Sociolinguistic constructions of identity'. Language in Society 25 (2), pp. 167-203.

Schrauf, R. W. (2000). 'Narrative repair of threatened identity'. Narrative Inquiry 10 (1), pp. 127145.

Scott, J. W. (1999). Gender and the Politics of History. New York: Columbia University Press.

Simpson, P. (2003). On the Discourse of Satire. Amsterdam and Philadelphia: John Benjamins Publishing Company.

Smith, Jr., W. S. (1980). 'Husband vs. wife in Juvenal's sixth satire'. The Classical World 73 (6), pp. 323-332.

Smith, W. S. (2008). 'Advice on sex by the self-defeating satirists: Horace Sermones 1.2, Juvenal Satire 6, and Roman satiric writing', in Smith, W. S. (ed.), Satiric Advice on Women and Marriage: From Plautus to Chaucer, Ann Arbor: The University of Michigan Press, pp. 111128.

Spivak, G. C. (1987). In Other Worlds: Essays in Cultural Politics. London and New York: Methuen.

Spivak, G. C. (1988). 'Can the subaltern speak?', in Nelson, C. and Grossberg, L. (eds.), Marxism and the Interpretation of Culture, Urbana: University of Illinois Press, pp. 271-313.

Spivak, G. C. (1990). The Post-Colonial Critic: Interviews, Strategies, Dialogues. New York and London: Routledge.

Spivak, G. C. (1999). A Critique of Postcolonial Reason: Towards a History of the Vanishing Present. Cambridge and London: Harvard University Press.

Swift, J. (1729). 'A modest proposal'. Dublin: S. Harding. URL: http://jonathanswiftarchive.org.uk/browse/text_10_8_1.html [Accessed 28 May 2015].

Swift, J. (2005). Gulliver's Travels. Oxford and New York: Oxford University Press.

Test, G. A. (1991). Satire: Spirit and Art. Gainesville: University Press of Florida.

Twark, J. E. (2007). Humour, Satire and Identity: Eastern German Literature in the 1990s. Berlin and New York: Walter de Gruyter.

Wedeen, L. (2013). 'Ideology and humour in dark times: Notes from Syria'. Critical Inquiry 39, pp. 841-873.

Williams, III, G. W. (2012). "Irony as the birth of Kierkegaard's "single individual" and the beginning of politics'. Toronto Journal of Theology 28 (2), pp. 309-318.

Wittig, M. (2007). 'One is not born a woman', in Richter, D. H. (ed.), The Critical Tradition: Classic Texts and Contemporary Trends $3^{\text {rd }}$ ed., Boston and New York: Bedfordist/St. Martin's, pp. 1637-1642.

Wright, B. (2011). "Why would you do that, Larry?": Identity formation and humour in Curb Your Enthusiasm'. The Journal of Popular Culture 44 (3), pp. 660-677.

Zekavat, M. (2014). 'A discursive model of satire'. JESELL (Jena Electronic Studies in English Language and Literature), pp. 1-18. URL: http://zs.thulb.unijena.de/receive/jportal_jparticle_00324293 [Accessed 24 November 2014]. 